ine : : inter

\title{
Growth hormone secretion in anestrous ewes subjected to prolonged stressful stimuli
}

\author{
F. Przekop ${ }^{1}$, P. Krejči ${ }^{2}$ and J. Slaba² \\ 'The Kielanowski Institute of Animal Physiology and Nutrition, \\ Polish Academy of Sciences \\ 05-110 Jablonna, Poland \\ 'Institute of Animal Physiology and Genetics, \\ Academy of Science of the Czech Republic \\ CR-104-00 Prague-Urhriněves, Czech Republic
}

(Received 14 July 1995; accepted 22 August 1995)

\begin{abstract}
The study was performed on 6 three-year-old Polish Merino ewes to examine the effects of prolonged intermittent footshock stimuli on the secretion of growth hormone (GH) in anestrous ewes. The state of stress was induced by electrical footshocks of enduring and repetitive character ( $20 \mathrm{~min} / \mathrm{h}, 9 \mathrm{~h}$ daily during 3 consecutive days, current intensity $3 \mathrm{~mA}$ ). The blood samples were taken at $2 \mathrm{~h}$ intervals on the day prior to stimulation (controls), during 3 days of footshock application. and on the post-stress day. The control levels of plasma GH were quite low (from 1 to $6 \mathrm{ng} / \mathrm{ml}$ ) and in some samples they were at, or near,the limit of detection. The mean $24 \mathrm{~h}$ plasma GH level ranged from 0.51 to $3.70 \mathrm{ng} / \mathrm{ml}$. The mean concentration of $\mathrm{GH}$ in all ewes prior to the exposure to footshock stress was $2.12 \pm 0.55$ (SE) $\mathrm{ng} / \mathrm{ml}$. Footshock led to marked increase in $\mathrm{GH}$ concentration; the mean plasma level of $\mathrm{GH}$ in animals reached about $200 \%$ of pre-stress values. There were no significant differences between GH responses in the first, second and third day of exposure to footshock stimuli. The mean level of plasma $\mathrm{GH}$ on the post-stress day did not differ significantly from the control concentration. However, in 4 out of 6 ewes the mean $24 \mathrm{~h}$ plasma GH level was lower as compared to the value found in controls. In conclusion, these results indicate that prolonged intermittent footshock stimulation increases $\mathrm{GH}$ secretion in anestrous ewes, after which the concentration of this hormone in the blood plasma in most animals on the post-stress day returns to normal, pre-stress values. It is suggested that changes in GII concentrations, among others, may be to some extent a valuable indicator of the biological cost of environmental challenges.
\end{abstract}




\section{INTRODUCTION}

It is generally accepted that prolonged or chronic stress causes major disorders in many physiological functions, including $\mathrm{GH}$ secretion which plays crucial role in the body's metabolic activity. Although certain neuroendocrine responses to stress may be adaptive mechanisms, the analysis of GH secretion in organisms under stressful conditions has an important aspect in understanding the physiology of stress. Numerous observations have shown that stress alters the pattern of $\mathrm{GH}$ secretion in a different manner in various species; in hamsters (Borer et al., 1982), monkeys (Brown et al., 1971; Meyer and Knobil, 1987) and men (Schalch, 1967; Schalch and Reichlin, 1968) stress increases GH secretion, while in rats (Day et al., 1983; Armario et al., 1986; Aquila et al., 1991; Benyassi et al., 1992; Franci etal., 1992) GH secretion is inhibited. Little is known about $\mathrm{GH}$ secretion under stressful conditions in farm animals. Experiments performed on cows revealed that $\mathrm{GH}$ secretion responds in a specific manner to different kinds of stressful stimuli (Munksgaard and Levendahl, 1993). It was found that long-term intermittent footshock stimuli of sheep elicits marked depletion of hypothalamic somatostatin (SRIF) but has no apparent effect on GH content in the growth hormone-producing cells of the anterior pituitary gland (Polkowska, 1989; Polkowska and Przekop, 1989). Lack of changes in GH concentration in the pituitary glands of stressed animals can not be easily interpreted since the hormone level in the pituitary cells reflects only the net result of its synthesis and release. On the other hand, growth hormone secretion in sheep was not influenced by cold exposure (Christensen et al.,1990). In the light of the presented results the species and/or stress specificity in the response of $\mathrm{GH}$ probably has different effects on the metabolic activity in the organism. As the first step to studying the mentioned problems, the present experiment was undertaken to follow the influence of prolonged intermittent electric stressful stimuli on the concentration of $\mathrm{GH}$ in the blood plasma of seasonally anestrous ewes.

\section{MATERIAL AND METHODS}

\section{Animals}

The experiment was performed on 6 three-year-old, seasonally anestrous, Polish Merino ewes. They were maintained indoors in individual pens and exposed to natural lighting conditions over the experimental period (March-April). Visual contact was allowed between the animals. To minimize the confounding effect of variable ovarian hormone levels on GH secretion, the 
experiment was performed on anestrous ewes. Feeds (hay and concentrates) and water were available ad libitum.

The animals were adapted to the experimental environment for at least six weeks before the study.

\section{Stressing procedure}

Stress was induced by applying a series of mild electrical footshocks of an enduring and repetitive character. Footshocks were applied through electrodes attached to both forelegs at the level of the metacarpus and connected to a $50 \mathrm{~Hz}$ sine wave generator. The generator was programmed to deliver repetitive trains of $3 \mathrm{~mA}(\mathrm{rms})$ alternating current ( $0.5 \mathrm{sec}$ on, $1 \mathrm{sec}$ off), arranged in series of ten. The series were repeated 35 times during the initial $20 \mathrm{~min}$ of each hour from 09.00 to $18.00 \mathrm{~h}$ for three consecutive days.

\section{Blood sample collection}

A catheter was introduced under local anesthesia into the jugular vein $24 \mathrm{~h}$ prior to the first blood collection. Twelve blood samples were drawn at $2 \mathrm{~h}$ intervals during 5 consecutive days (i.e. one day prior to the onset of the stressful stimulation, during three days of the stimulation, and on the day after the stimulation). The blood was centrifuged at $3.000 \mathrm{~g}$ for $10 \mathrm{~min}$ at $4^{\circ} \mathrm{C}$ and plasma was stored at $-20^{\circ} \mathrm{C}$ until analysis.

\section{GH assay}

GH was determined by routine double antibody radioimmunoassay (Dvorak et al., 1987). In order to increase the precision of estimation, all samples were analyzed within one series of RIA. The assay detection limit was $0.034 \mathrm{ng}$ corresponding to $0.68 \mathrm{ng} / \mathrm{ml}$ of plasma sample. The coefficient of variation calculated for control samples at concentrations of $0.1,0.8$ and $6.4 \mathrm{ng} / \mathrm{ml}$ of $\mathrm{GH}$ was $7.4,2.6$ and $5.5 \%$, respectively. The mean concentration of $\mathrm{GH}$ for an individual animal was calculated from the area under the curve (sum of trapezoid areas between curve and abscissa).

\section{Statistics}

Data are presented as means \pm SEM. Statistical analysis was performed using the two-tailed nonparametric two-way analysis of variance followed by multiple comparisonson ranks of several related samples as described by Theodorson-Norheim (1987). Significance was defined at a level lower than 0.05 . 


\section{RESULTS}

In non-stressed anestrous ewes, plasma levels of $\mathrm{GH}$ were quite low (from 1 to $6 \mathrm{ng} / \mathrm{ml}$ ) and in some samples they were at, or near, the assay sensitivity limit. In these animals, the mean $24 \mathrm{~h}$ plasma GH level ranged from 0.51 to $3.70 \mathrm{ng} / \mathrm{ml}$. The mean level of $\mathrm{GH}$ in six ewes before exposure to footshock stress was $2.12 \pm 0.55 \mathrm{ng} / \mathrm{ml}$.

Footshock application led to a marked increase in GH concentration in the blood plasma (Figure 1). The mean concentration of $\mathrm{GH}$ in six ewes reached about $200 \%$ of pre-stress values (Figure 2 ). There were no significant differences between $\mathrm{GH}$ responses to footshock stress on the first, second or third day of exposure (Figures 1 and 2). The mean level of plasma GH on the post-stress day did not differ significantly from the control value (Figures 1 and 2). In four out of six ewes, however, the mean $24 \mathrm{~h}$ plasma GH level was lower on the post-stress

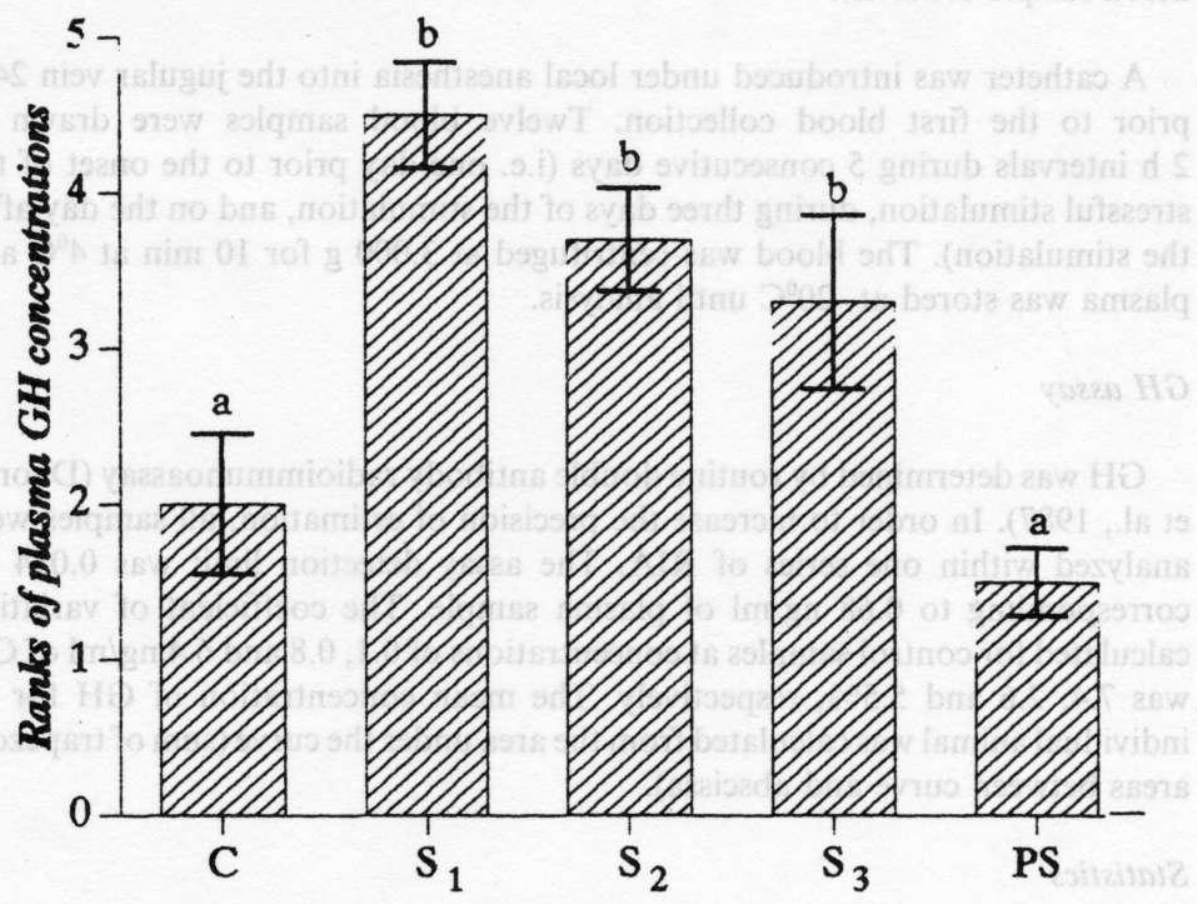

Figure 1. The average ranks of mean daily levels of growth hormone $(\mathrm{GH})$ in the blood plasma of ewes before (C), during (S) and after (PS) footshocking $\mathrm{S}_{1}, \mathrm{~S}_{2}, \mathrm{~S}_{3}$ - consecutive days of footshocking; different letters denote the significance between groups $\mathrm{S}_{1}$ vs $-\mathrm{P} \leqslant 0.01 ; \mathrm{S}_{2}$ vs $-\mathrm{P} \leqslant 0.025 ; \mathrm{S}_{3}$ vs $-\mathrm{P} \leqslant 0.05$ 


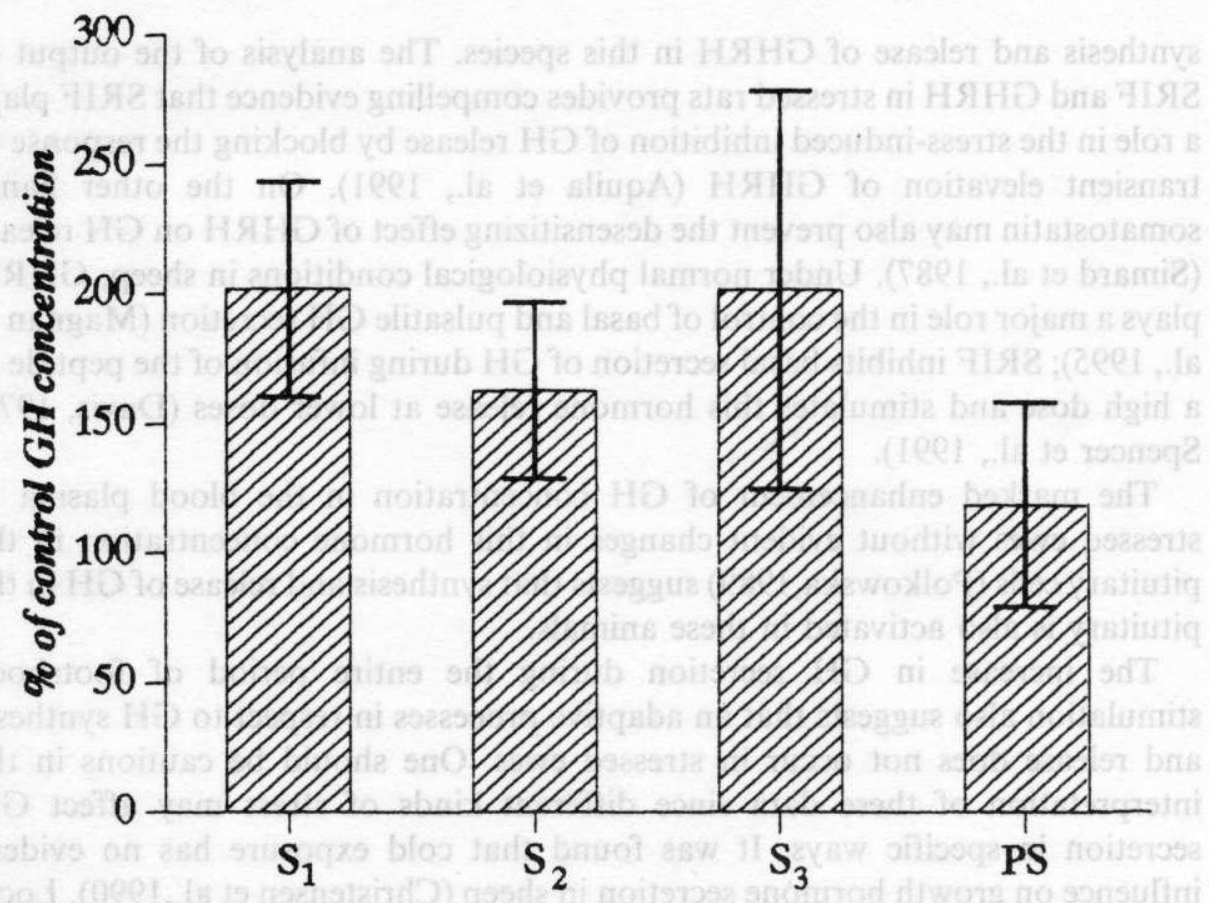

Figure 2. The mean concentrations of plasma growth hormone $(\mathrm{GH})$, expressed as a percentage of respective control value (100\% - the mean daily levels of $\mathrm{GH}$ on the day before the onset of footshocks), in ewes during (S) and after (PS) footshocking

$\mathrm{S}_{1}, \mathrm{~S}_{2}, \mathrm{~S}_{3}$ - consecutive days of footshocking

day as compared to the one found under control conditions. The mean GH concentration found in these four ewes on the post-stress day attained $64.7 \pm 16.4 \%$ of there spective pre-stress value.

\section{DISCUSSION}

The increase of GH concentration in the blood plasma of anestrous sheep exposed to prolonged intermittent footshocks provides evidence that stress facilitates $\mathrm{GH}$ release. The theoretically, this suggests that the excitatory effect of GHRH and other stimulatory factor(s) released from the hypothalamus of stressed ewes overcomes the inhibitory influence of simultaneously liberated SRIF on GH secretion from pituitary cells. Indeed, it has been found in our Laboratory that this kind of stress elicits activation of SRIF release from the hypothalamus and median eminence (Polkowska and Przekop, 1988). Unfortunately, there is still a lack of studies concerning the effect of stress on the 
synthesis and release of GHRH in this species. The analysis of the output of SRIF and GHRH in stressed rats provides compelling evidence that SRIF plays a role in the stress-induced inhibition of $\mathrm{GH}$ release by blocking the response to transient elevation of GHRH (Aquila et al., 1991). On the other hand, somatostatin may also prevent the desensitizing effect of GHRH on GH release (Simard et al., 1987). Under normal physiological conditions in sheep, GHRH plays a major role in the control of basal and pulsatile GH secretion (Magnan et al., 1995); SRIF inhibits basal secretion of GH during infusion of the peptide at a high dose and stimulates this hormone release at lower doses (Davis, 1975; Spencer et al., 1991).

The marked enhancement of GH concentration in the blood plasma in stressed ewes without evident changes in this hormone concentration in the pituitary cells (Polkowska,1989) suggests that synthesis and release of GH in the pituitary is also activated in these animals.

The increase in GH secretion during the entire period of footshock stimulation also suggests that an adaptive processes in respect to $\mathrm{GH}$ synthesis and release does not occur in stressed ewes. One should be cautions in the interpretation of these data since different kinds of stress may affect $\mathrm{GH}$ secretion in specific ways. It was found that cold exposure has no evident influence on growth hormone secretion in sheep (Christensen et al.,1990). Local electrical stimulation of the median eminence in sheep evokes a biphasic effect on GH secretion: inhibition followed by stimulation (Malven, 1975). The consequence of the increased secretion of $\mathrm{GH}$ which was observed in our experiments with concomitant enhanced cortisol and prolact in release (Przekop et al., 1985; Wolińska et al., 1986; Polkowska and Przekop, 1988) may, among others, seriously disorder the physiological metabolic processes in the organism.

On the day after stimulation, the GH concentration declined in most animals to below control values. In the light of these results we can not offer a precise explanation for this phenomenon. It seems reasonable only to suggest that the decrease in the plasma GH concentration on the post-stress day may be a result of decreased release, increased utilization or both of these events. Taken together, the above-mentioned results and our data suggest that $\mathrm{GH}$ secretion in stressed ewes is dependent to a large degree upon the nature of the stress applied.

In conclusion, these results indicate that prolonged intermittent footshock stimulation in creases secretion of GH in anestrous ewes and leads to a decrease of this hormone concentration on the post-stress day. They suggest that alternations in GH levels, among others, may affect metabolic processes in the organism and may to some extent be a valuable indicator of the biological cost of different environmental challenges. 


\section{REFERENCES}

Aquila M.C., Pickle R.C., Ya W.H., McCann M.S., 1991. Roles of somatostatin and growth hormone-releasing factor in ether stress inhibition of growth hormone release. Neuroendocrinology $54,515-520$

Armario A., López-Calderón A., Jolin T., Balasch J., 1986. Response of anterior pituitary hormone to chronic stress. The specificity of adaptation. Neurosci. Behav. Rev. 10, 245-250

Basset J.M., 1976. Diurnal patterns of plasma insulin, growth hormone, corticosteroids and metabolite concentration in fed and fasted sheep. J. Biol. Sci. 27, 167-181

Benyassi A., Gavalda A., Armario A., Araneibia S., 1992. Role of somatostatin in acute immobilization stress-induced GH decrease in rat. Life Sci. 52, 361-370

Borer K.T., Kalch R.P., Hayashida, 1982. Hamster growth hormone. Species specificity and physiological changes in blood and pituitary concentrations as measured by homologous radioimmunoassay. Neuroendocrinology $35,349-358$

Brown G.M., Schalch D.S., Reichlin S., 1971. Patterns of growth hormone and cortisol responses to psychological stress in the squirrel monkey. Endocrinology 88, 956-963

Christensen R.A., Christopherson R.J., Kennelly J.J., 1990. Effect of somatostatin and chronic cold exposure on hormonal and metabolic concentration, metabolic rate, thermoregulation and gut motility in sheep. Can. J. Anim. Sci. 70, 1073-1083

Davis S.L., 1975. Somatostatin: its influence on plasma levels of growth hormone, prolactin and thyrotropin in sheep. J. Anim. Sci. 40, 911-916

Day T.A., West M.J., Willoughby J.O., 1983. Stress suppression of growth hormone secretionin the rat: effects of disruption of inhibitory noradrenergic afferents to the median eminence. Aust. J. Biol. Sci. 36, 525-530

Dvorak P., Becka S., Krejci P., Chropova M., 1978. Radioimmunoassays of bovine growth hormone. Biochem. Radioanal. Letters 34, 155-160

Franci C.R., Anselmo-Franci J.A., McCann S.M., 1992. The role of endogenous atrial natriuretic peptide in resting and stress induced release of corticotropin, prolactin, growth hormone, and thyroid stimulating hormone. Proc. Nat. Acad. Sci. USA 23, 11391-11395

Malven P.V., 1975. Immediate release of prolactin and biphasic effect on growth hormone release following electrical stimulation of the median eminence. Endocrinology 97, 808-815

Meyer V., Knobil E., 1967. Growth hormone secretion in the unanesthetized rhesus monkey in response to noxious stimuli. Endocrinology 80, 163-171

Müller E.E., 1987. Neural control of somatotropic function. Physiol. Rev. 67, 962-1053

Munksgaard L., Levendahl P., 1993. Effects of social and physical stressors on growth hormone levels in dairy cows. Can. J. Anim. Sci. 73, 847-853

Polkowska J., Przekop F., 1988. Immunocytochemical changes in hypothalamic and pituitary hormones after acute and prolonged stressful stimuli in the anestrous ewe. Acta Endocrinol. $118,269-276$

Polkowska J., 1989. The effect of long-term stress on hypothalamic somatostatin (SRIF) and growth hormone $(\mathrm{GH})$ immunocytochemistry in the anestrous ewe. In: K. Boda (Editor), Endocrinology of Farm Animals, Proceedings of the II International Symposium on Farm Animal Endocrinology, Smolenice Castle, Czechoslovakia. Institute of Animal Physiology. Slovak Academy of Sciences, Košice, pp. 261-266

Przekop F., Stupnicka E., Wolińska-Witort E., Mateusiak K., Sadowski B., Domański E., 1985. Changes in circadian rhythm and suppression of plasma cortisol level after prolonged stress in the sheep. Acta Endocr. 110, 540-545

Schalch D.S., Reichlin S., 1968. Stress and growth hormone release. In: A. Pecilo, E.E. Müller (Editors), Growth hormone, Exerpta Medica Foundation, Amsterdam, pp. 211-225 
Simard J., Lefévre G., Labrie F., 1987. Somatostatin prevents the desensitizing action of growth hormone-releasing factor on growth hormone release. Peptides 8, 199-205

Spencer G.S.G., Bass J.J., Hodgkinson S.C., Dobbie P., 1991. Neuroendocrine regulation of growth hormone secretion in sheep. II. Effect of somatostatin on growth hormone and glucose levels. Domestic Anim. Endocr. 8, 375-381

Wolińska-Witort E., Przekop F., Mateusiak K., Domański E., 1986. Effect of repeated and prolonged stress stimuli on the plasma prolactin concentration in sheep. Exp. Clin. Endocrinol. $87,265-276$

\section{STRESZCZENIE}

\section{Sekrecja hormonu wzrostu u anestralnych owiec w warunkach długotrwalego stresu}

Badania nad wpływem długoterminowego stresu na sekrecję hormonu wzrostu prowadzono na sześciu trzyletnich maciorkach rasy merynos Polski w okresie anestralnym. Stres wywoływano łagodnymi 20 minutowymi impulsami prądu o natężeniu $3 \mathrm{~mA}$ w ciągu godziny przez 9 godzin dziennie przez 3 kolejne dni. Próbki krwi do analiz hormonu wzrostu pobierano co 2 godz przez całą dobę przed poddaniem zwierząt stresowi (próby kontrolne), w ciągu trzech dni stymulacji i przez jeden dzień po zakończeniu stresu. Przed stymulacją poziom hormonu wzrostu w osoczu krwi był niski i wahał się od 0 do $6 \mathrm{ng} / \mathrm{ml}$ (średnio $2,12 \pm 0,05$ ). Stres powodował istotny wzrost stężenia hormonu w osoczu i osiągnął dwukrotną wartość w stosunku do uzyskanej od zwierząt kontrolnych $(\mathrm{P} \leqslant 0,05)$ a stężenie to było podobne w każdych z trzech dni stymulacji. Średnie stężenie hormonu wzrostu po zakończeniu stymulacji w ostatnim dniu doświadczenia powracało do wartości uzyskanych w okresie kontrolnym, a u czterech z sześciu zwierząt było nawet niższe niż przed stymulacją.

Uzyskane wyniki sugerują, że zmiany sekrecji hormonu wzrostu w czasie stresu mogą być jednym $\mathrm{z}$ istotnych czynników zmieniających procesy metaboliczne i mogą odzwierciedlać wpływ środowiska na organizm. 